\title{
Influence of Thermal and Bacterial Pretreatment of Microalgae on Biogas Production in Mesophilic and Thermophilic Conditions
}

\author{
Beti Vidmar, ${ }^{1}$ Romana Marinšek Logar, ${ }^{1}$ Mario Panjičko ${ }^{2}$ and Lijana Fanedl ${ }^{1, *}$ \\ ${ }^{1}$ Chair of Microbiology and Microbial Biotechnology, Department of Animal Science, Biotechnical Faculty, \\ University of Ljubljana, Groblje 3, 1230 Domžale, Slovenia \\ ${ }^{2}$ Sustainable Technologies Development Centre Ltd (CROTEH), Dragutina Golika 63, HR-10020 Zagreb, Croatia \\ * Corresponding author: E-mail: Lijana.Fanedl@bf.uni-li.si \\ Tel: 0038613203835
}

Received: 23-11-2016

\begin{abstract}
Microalgae biomass has a great potential in search for new alternative energy sources. They can be used as a substrate for the biogas production in anaerobic digestion. When using microalgae, the efficiency of this process is hampered due to the resistant cell wall. In order to accelerate the hydrolysis of cell wall and increase the efficiency of biogas production we applied two different pretreatments - biological and thermal under mesophilic and thermophilic conditions. During biological pretreatment we incubated microalgae with anaerobic hydrolytic bacteria Pseudobutyrivibrio xylanivorans $\mathrm{Mz} 5^{\mathrm{T}}$. In thermal pretreatment we incubated microalgae at $90{ }^{\circ} \mathrm{C}$. We also tested a combined thermal and biological pretreatment in which we incubated $P$. xylanivorans $\mathrm{Mz} 5^{\mathrm{T}}$ with thermally pretreated microalgae. Thermal pretreatment in mesophilic and thermophilic process has increased methane production by $21 \%$ and $6 \%$, respectively. Biological pretreatment of microalgae has increased methane production by $13 \%$, but only under thermophilic conditions (pretreatment under mesophilic conditions showed no effect on methane production). Thermal-biological pretreatment increased methane production by $12 \%$ under thermophilic conditions and by $6 \%$ under mesophilic conditions.
\end{abstract}

Keywords: biogas production; anaerobic digestion; microalgae; biological pretreatment; thermal pretreatment; Pseudobutyrivibrio xylanivorans $\mathrm{Mz}^{\mathrm{T}}$

\section{Introduction}

Global human population growth, rapid technological development, climate changes and depletion of fossil fuels have led to an accelerated search for new renewable energy sources. Renewable energy sources are rapidly evolving area with positive effects on the environment (with little or zero carbon dioxide emissions and substrate low sulfur content) and promising economic aspect. ${ }^{1}$ Given alternative energy sources provoked a lot of controversy, despite initial positive expectations.

Renewable energy sources are classified into groups; first generation biofuels (derived exclusively from crops of cultivated plants) and second generation biofuels (derived from lignocellulosic biomass) ${ }^{2-4}$ have serious flaws, including a great need for arable land and large amount of consumed water. They are also creating a lot of pressure on agriculture and have a low productivity, since produced biomass cannot cover global demand. ${ }^{5}$

In recent decades we are witnessing increase in interest of exploitation of the algae energy potential. Algae biomass represents the substrate for rapidly developing group of third generation biofuels. This generation offers the perfect solution for solving the above-mentioned drawbacks. ${ }^{6}$ The main advantages of using algae are low water consumption (they can be grown in salty, waste and non-potable water), possible production on uncultivated areas with high carbon dioxide concentrations, theoretical high photosynthetic efficiency and high productivity. ${ }^{7,8}$

For a long time technology focused mainly on obtaining biodiesel from algae biomass, which proved to be energy consuming and unbalanced process. More simple process for supplying renewable energy is anaerobic digestion (AD). ${ }^{9,10}$ Biogas from $\mathrm{AD}$ is an alternative, but 
much more economically and energetically-favourable process. $^{8}$

Microbial anaerobic methanogenic process is applied for the multistep decomposition of organic substrates into biogas. Biogas consists of different gases - methane $(\sim 65 \%)$, carbon dioxide $(\sim 35 \%)$ and others (nitrogen, nitrogen oxides, hydrogen, ammonia and hydrogen sulfide). ${ }^{11}$ Other products in $\mathrm{AD}$, such as heat and digestate can be used in other processes or as a soil conditioner. ${ }^{8}$ Efficacy of AD is influenced by various factors such as composition of substrates, carbon and nitrogen ratio $(\mathrm{C}: \mathrm{N})$ of digester contents, composition of microbial community, degree of mixing, $\mathrm{pH}$ and temperature. It has been shown that among technological parameters temperature and $\mathrm{pH}$ have the biggest impact on speed of the biogas production. ${ }^{12-15}$ The process of anaerobic degradation can run under psychrophilic $\left(<20^{\circ} \mathrm{C}\right)$, mesophilic $\left(25-40{ }^{\circ} \mathrm{C}\right)$ or thermophilic $\left(50-65{ }^{\circ} \mathrm{C}\right)$ conditions. ${ }^{16,17}$ Technically speaking, the industry is only interested in mesophilic and thermophilic process, ${ }^{18}$ since the decomposition at lower temperatures is very slow. ${ }^{19}$ When speaking about AD of the same substrates the mesophilic and thermophilic processes are distinguished mainly by their composition of microbial community, resulting in biogas production differences from the same substrate. ${ }^{20,21,22}$ There are some important microbiological characteristics associated with thermophilic anaerobes, which may affect the biogas production. These characteristics include slow bacterial growth, high cell death, lower bacteria variety, which show an effect on relatively high fatty acids concentration (more than $1 \mathrm{~g} \mathrm{l}^{-1}$ ), reduced substrate degradation etc. ${ }^{21}$ Since AD is a multi-step process, it is depending on interactions among bacterial and archaeal microbial communities and their substrate and product specificities. Knowledge about the dynamics of microbial community structure and activity is essential for successful planning of the biogas process, monitoring its parameters and for reaching main goal: process stability and maximum yield. ${ }^{23}$ The link between community structure and performance is still not completely clear and more studies are needed. $^{24,25}$

Mesophilic conditions represent the optimum temperature range for larger group of microorganisms (anaerobic bacteria and archaea), as thermophilic conditions. Nevertheless the most important fact is to maintain a stable temperature, irrespective of applied process. ${ }^{20}$ Biochemical reactions at higher temperatures are faster therefore the degradation is faster too. Generally, but not always, thermophilic $\mathrm{AD}$ is up to 8-times faster and up to 4-times more productive than mesophilic. It allows better organic matter decomposition and increased biogas production (up to $36 \%$ ), although the actual methane yield in thermophilic AD is dependent on substrate composition and its $\mathrm{C}: \mathrm{N}$ ratio. Higher temperature also enables thermal destruction of pathogenic bacteria, which is considered as a big advantage over other processes. Disadvantages of thermophilic AD are instability, higher energy inputs and in comparison to the mesophilic process higher temperatures can cause reduced $\mathrm{CO}_{2}$ solubility, which leads to higher proportion of free ammonium and increase in $\mathrm{pH} .{ }^{20}$

Microalgae represent a promising substrate for AD, because they are rich in nutrients, such as carbon, nitrogen and phosphorus, which are essential for the anaerobic microorganisms. Microalgae cells contain a lot of water (78-90\%), ${ }^{26,27}$ many species have high content of carbohydrates (up to $64 \%$ of their dry matter) and lipids (2-75\% of their dry matter). ${ }^{28,29}$ Carbohydrates occur in the form of starch, cellulose and various sugars ${ }^{30}$ so the substrate is suitable for microbial fermentation. Freshwater microalgae species can contain up to $31 \%$ free fatty acids (FFA), but the composition of FFA and lipids is heavily depending on growth conditions (light, temperature, nitrogen level, growth stage at which they are harvested). ${ }^{31}$ In comparison to carbohydrates and proteins, lipids have higher theoretical potential for methane production. Nevertheless, when the buffer capacity of the system is low, higher lipid content can result in formation of intermediate products (long chain fatty acids) during $\mathrm{AD}$ and consequently process inhibition. ${ }^{32}$ Some species of microalgae may contain lignin $(<2 \%),{ }^{33}$ a high level of cellulose $(7,1 \%)$ and hemicellulose $(16,3 \%) .{ }^{34}$ High ash contents are typical for winter months and in early spring. The C:N ratio is around 10:1.34,35

Despite the positive aspects of microalgae as substrate for biogas production, we may encounter several problems that also limit their use for anaerobic decomposition. Problems may occur due to low concentration of biodegradable substrate, cell walls resistant to biodegradation, low $\mathrm{C}: \mathrm{N}$ and sometimes higher lipids concentrations. ${ }^{32}$

Some green algae are covered by multiple layers of intricately sculpted scales while others have crystalline glycoprotein coverings or thick multilaminate fibrillar cell walls. A few taxa though have cell walls with remarkable structural and biochemical similarity to cell walls found in land plants. ${ }^{36}$ As an example we can take a known representative of the genus Scenedesmus, wherein the rigid cell wall is composed of glucose, mannose and galactose. Individual sugars are otherwise well biodegradable, but in the cell wall they are linked together and form cellulose, hemicellulose and some other polymers (e.g. sporopollenin). These molecules form a strong cell wall, highly resistant to bacterial degradation. ${ }^{10}$

One of the possible solutions to enhance the AD of microalgae biomass are different types of pretreatments, which we use in order to make substrate more susceptible to biodegradation. ${ }^{37}$ Pretreatments can be divided into four groups - thermal, mechanical, chemical and biological. Most studied area is thermal pretreatment of microalgae biomass, which shows favourable results and certain industrial processes already run continuously. Mechanical pretreatment generally requires more energy input in 
comparison to the chemical, thermal or biological treatments. Chemical pretreatment has proved successful, especially in combination with thermal, but the main disadvantage is contamination and complexity of downstream processes. Biological pretreatment of biomass is also very promising, mainly due to low energy consumption. ${ }^{38}$

In the presented research work the biodegradability of untreated and pretreated microalgae was examined in anaerobic digestion. In order to accelerate the hydrolysis and increase the efficiency of biogas production two different pretreatments were applied - biological (bacterial) and thermal. A combined thermal-biological pretreatment was tested, too. Biogas production was measured in biochemical methane potential assay under mesophilic and thermophilic conditions.

\section{Experimental}

\section{1. Substrate for Biogas Production}

Microalgae biomass was obtained from the open photobioreactor of company Koto d.o.o. Microalgae are produced in digestate (liquid part of the effluent after separation to liquid and solid part) of thermophilic biogas reactor, which converges into $26 \mathrm{~m}^{3}$ big pool. Microalgae biomass was pumped out of the pool with a peristaltic pump and stored in larger containers, later divided into smaller volumes (up to $1 \mathrm{l}$ ) and frozen at $-20^{\circ} \mathrm{C}$. Chemical composition of the dry microalgae biomass is shown in Table 1.

Table 1. Chemical composition of the dry microalgae biomass. Legend: TVS (total volatile solids), TOC (total organic carbon), TN (total nitrogen) (Determined by Koto d.o.o.).

\begin{tabular}{cc}
\hline Parameters & Content $\left(\mathbf{g ~ k g}^{\mathbf{- 1}}\right)$ \\
\hline TVS & 796,8 \\
TN & 70,7 \\
Ash & 203,2 \\
Protein & 441,3 \\
TOC & 404,8 \\
C:N ratio & 5,7 \\
\hline
\end{tabular}

\section{2. Microbial Inoculum for Biogas Production}

Two different microbial inoculums were used to test the differences between mesophilic and thermophilic process of biogas production. Mesophilic microbial inoculum was taken from an active CSTR (continuous stirred-tank reactor) operating at $37^{\circ} \mathrm{C}$ (biogas plant Petrol d.d., Slovenia). Before the experiment, the microbial inoculum was pre-incubated for eight days at $37^{\circ} \mathrm{C}$. Thermophilic microbial inoculum was taken from CSTR operating at $55{ }^{\circ} \mathrm{C}$ (biogas plant Koto d.o.o., Slovenia) and was pre-incubated for eight days at $55^{\circ} \mathrm{C}$.

\section{3. Pretreatment of Microalgae Biomass}

The temperature of $90{ }^{\circ} \mathrm{C}$ was applied for thermal treatment of microalgae in this experiment. The selected temperature based on previous research reports. ${ }^{10} \mathrm{Mi}-$ croalgae were first thawed, thoroughly mixed and distributed into glass bottles of $250 \mathrm{ml}$. The bottles were closed with gas-tight rubber and aluminium stoppers. Thermal pretreatment of microalgae was conducted in water bath for three hours at $90{ }^{\circ} \mathrm{C}$. Occasionally the bottles were mixed and vented.

Bacterial strain Pseudobutyrivibrio xylanivorans $\mathrm{Mz}^{\mathrm{T}}$ (DSM 14809) originates from the microbial collection of the Department of Microbiology and Microbial Biotechnology at Biotechnical Faculty and was used for biological pretreatment of microalgae biomass. P. xylanivorans $\mathrm{Mz}^{\mathrm{T}}$ holds excellent cellulolytic, xylanolytic, amylolytic and pectinolytic activity ${ }^{39,40}$ Due to these characteristics, P. xylanivorans $\mathrm{Mz} 5^{\mathrm{T}}$ was selected for biological pretreatment of microalgae.

The bacterium was cultured in DSMZ medium M330 $(50 \mathrm{ml})$ and incubated overnight $(\sim 20 \mathrm{~h})$ at $37{ }^{\circ} \mathrm{C}$. When the culture reached optical density $(\lambda=600 \mathrm{~nm}) 0,5$ $\pm 0,05$, it was centrifuged and the precipitate was anaerobically transferred into 11 batch reactors to pretreat microalgae biomass. Pretreatment was carried out for 24 hours at $37{ }^{\circ} \mathrm{C}(120 \mathrm{rpm})$, then microbial inoculum was added to the substrate.

\section{4. Experimental Setup of Biochemical Methane Potential (BMP) Assay}

BMP assay was conducted to examine and determine the effect of different microalgae pretreatments on biogas and methane production. On the first day biological and thermal pretreatments were performed, but the BMP assay started the second day. Experimental setup was the same for both processes (mesophilic and thermophilic), as seen on Figure 1.

For biological pretreatment we incubated $P$. xylanivorans $\mathrm{Mz} 5^{\mathrm{T}}$ together with untreated microalgae (as described in chapter 2.3), for thermal pretreatment only thermally pretreated microalgae (as described in chapter 2.3) were added and for thermal-biological pretreatment we incubated $P$. xylanivorans $\mathrm{Mz} 5^{\mathrm{T}}$ with thermally pretreated microalgae. All pretreatments lasted for 24 hours, after which methanogenic microbial inoculum was added to the experimental bottles to start the anaerobic digestion.

Before experiments the appropriate loading of the bioreactors was determined by measuring TTS (total solids) and TVS (total volatile solids) for both microbial inoculums and chemical oxygen demand (COD) for microalgae. ${ }^{41}$ The microbial inoculum concentration for both experiments was $4 \mathrm{~g} \mathrm{TVS}^{-1}$ and microalgae loading was $1,228 \mathrm{~g}$ TVS (144 ml).

Phosphate buffer $(20 \mathrm{ml})$ and anoxic tap water were added to all experimental mixtures. Working volume for 
all mixtures was $500 \mathrm{ml}$. Sole microbial inoculum served as a negative control for residual methanogenic activity. For positive control (standard), which represents the internal control for BMP assay, glucose was added as a substrate. Loading for standard mixtures was $0,748 \mathrm{~g} \mathrm{l}^{-1}(0,2 \mathrm{~g}$ $\left.\mathrm{COD}_{\text {glucose }}\right)$. While mixing all ingredients, anaerobic conditions were maintained by sparging gaseous nitrogen. ${ }^{42}$ Mixtures with autoclaved culture of P. xylanivorans $\mathrm{Mz}^{\mathrm{T}}$ were tested to measure the medium's nutrients and dead cell COD effect (negative control to experimental mixtures with live culture of MZ5) on biogas production. Both experiments were conducted in laboratory bioreactors $(1 \mathrm{l})$ at $37{ }^{\circ} \mathrm{C}$ for mesophilic conditions and at $55^{\circ} \mathrm{C}$ for thermophilic conditions. The bioreactors were kept in dark at $120 \mathrm{rpm}$ for 46 days (thermophilic process) and 55 days (mesophilic process) with three replicate experimental mixtures.

In order to gain information on the cumulative biogas production in each mixture, after each measurement the volume of produced biogas was added to the sum of previous measurements. In presentation of the final results of biogas production the amount of generated biogas in negative control was also taken into account. To calculate the net quantity of the produced biogas (how much biogas was generated at the expense of the added substrate), the average amount of biogas produced in ne- gative controls was subtracted from the production of the test mixtures. The same was done for cumulative methane production. The resulting methane yields were normalized to standard conditions as described by Hansen et. al (2004). ${ }^{43}$

\section{5. Analytical Methods}

TTS and TVS of experimental mixtures were determined at the beginning $\left(t_{0}\right)$ and the end $\left(t_{46}\right.$ for thermophilic and $t_{55}$ for mesophilic process) of each experiment according to standard methods. ${ }^{41}$ COD was also performed, using closed reflux method. ${ }^{41}$ The $\mathrm{pH}$-values of mixtures were measured at the beginning $\left(\mathrm{t}_{0}\right)$ and the end $\left(\mathrm{t}_{46}\right.$ for thermophilic and $t_{55}$ for mesophilic process) of each experiment.

The quantity and composition of produced biogas was determined 12 times during both processes. Shortchain fatty acids (SCFAs) were monitored 4 times during both processes. The amount of produced biogas was measured manually with a pressure gauge and water column. ${ }^{43}$ The proportion of methane, carbon dioxide and nitrogen was monitored by Shimadzu 14A gas chromatograph (GC) equipped with thermal conductivity detector (TCD). The separation of gases was carried out on a steel column (diameter 1/8") filled with PORAPAK Q (Agilent). He-

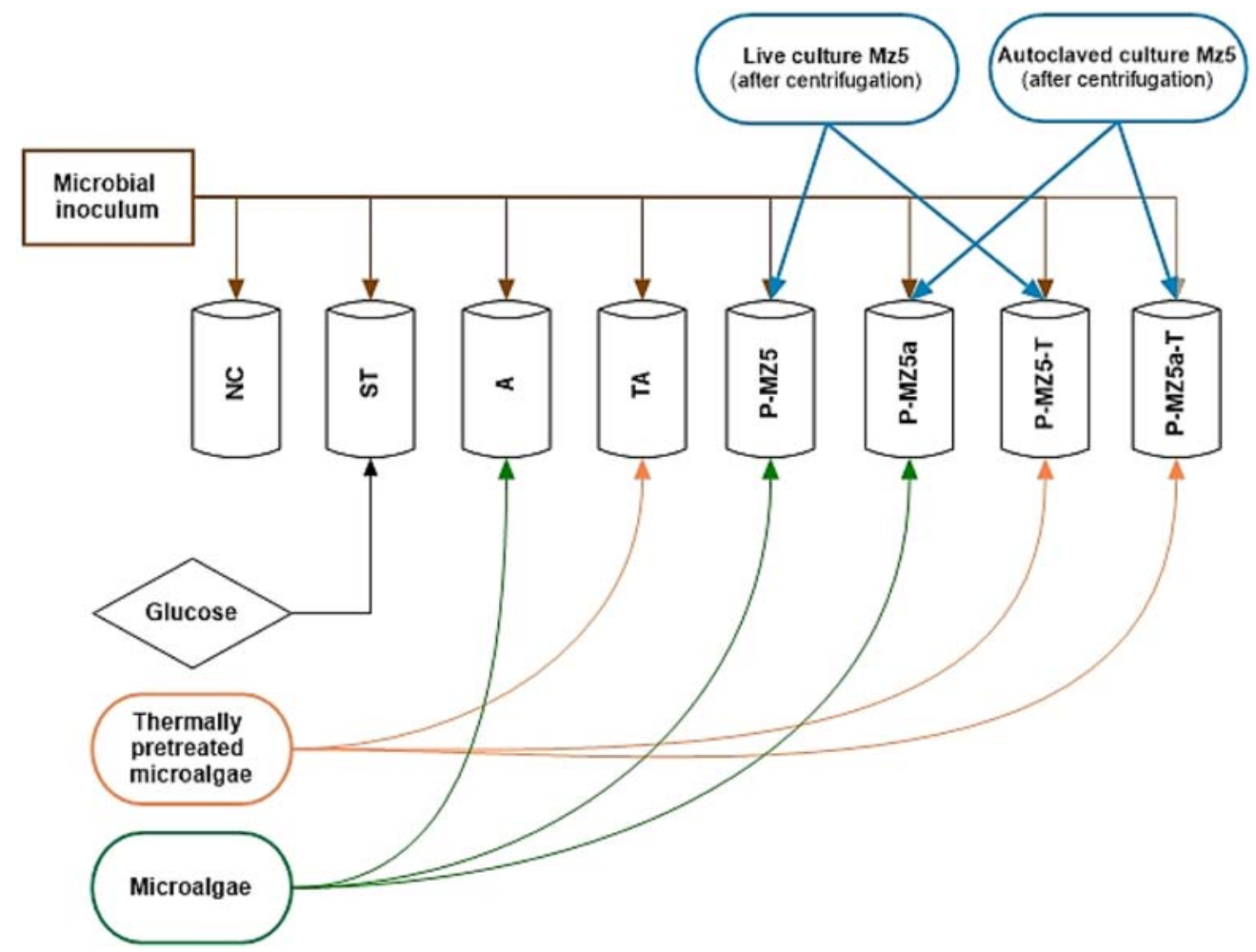

Figure 1. Experimental set-up for BMP assays. NC - negative control (microbial inoculum), ST - standard respectively positive control, A - untreated microalgae, TA - thermally pretreated microalgae, P-MZ5 - biologically pretreated microalgae (Mz5 culture added), P-MZ5a - negative control for biologically pretreated microalgae (autoclaved Mz5 culture added), P-MZ5-T - thermally and biologically pretreated microalgae (Mz5 culture added), P-MZ5a-T - negative control for thermally and biologically pretreated microalgae (autoclaved Mz5 culture added). 
lium with flow rate of $25 \mathrm{ml} \mathrm{min}{ }^{-1}$ was used as a gas carrier. For analysis, we used the following program: injector temperature was $50{ }^{\circ} \mathrm{C}$, column temperature $30^{\circ} \mathrm{C}$, detector temperature $80^{\circ} \mathrm{C}$, current was $60 \mathrm{~mA}$. Standard mixture of gases $\left(15,7 \% \mathrm{H}_{2}, 18,7 \% \mathrm{~N}_{2}, 20,5 \% \mathrm{CH}_{4}\right.$ and $45,1 \%$ $\mathrm{CO}_{2}$ ) was used for calibration performed using the method of surface normalization. The resulting methane yields were normalized to standard conditions and expressed in normalized volume percentage.

Ether extraction of SCFAs was performed according to the adapted method. ${ }^{44}$ SCFAs were determined by GC equipped with a flame ionization detector (FID). Helium was used as a gas carrier. For analysis, we used the following program: injector temperature was $250{ }^{\circ} \mathrm{C}$, column initial temperature $80^{\circ} \mathrm{C}$, column final temperature 160 ${ }^{\circ} \mathrm{C}$, detector temperature $250{ }^{\circ} \mathrm{C}$, time of maintaining the initial column temperature was 2 minutes and time of final temperature maintenance was 4 minutes. Column was heated at a rate of $15{ }^{\circ} \mathrm{C}$ per minute. Quantification was performed by an internal standard method (crotonic acid, $100 \mathrm{mg} \mathrm{ml}^{-1}$ ).

\section{Results and Discussion}

\section{1. Biogas and Methane Production from Microalgae}

\section{1. 1. Mesophilic Process}

The highest biogas production under mesophilic conditions resulted from thermal pretreatment of microalgae (TA) with the average production of $452,9 \mathrm{ml}$ per $1 \mathrm{~g}$ $\mathrm{TVS}_{\text {substrate }}$. The lowest production was recorded in case of biological pretreatment of microalgae (P-MZ5), with the average production of $324,5 \mathrm{ml}$ biogas per $1 \mathrm{~g} \mathrm{TVS}_{\text {substrate }}$ (Figure 2, A).

The highest methane production was recorded for mixtures with thermally pretreated microalgae (TA), with the average production of $273,2 \mathrm{ml}$ of methane per $1 \mathrm{~g}$ $\mathrm{TVS}_{\text {substrate }}$. The lowest production of methane was measured in case of untreated microalgae (A), with average production of 217,2 $\mathrm{ml}$ of methane per $1 \mathrm{~g} \mathrm{TVS}_{\text {substrate }}$ (Figure $2, \mathrm{~B})$. The average percentage of methane in biogas in mesophilic process on the last day of BMP assay represented $64,1 \%$. The trend showed that each of the pretreatments slightly increased the methane proportion in produced biogas (Table 3).

\section{1. 2. Thermophilic Process}

The maximal biogas production under thermophilic conditions was measured in case of microalgae biologically pretreated with bacteria $P$. xylanivorans $\mathrm{Mz}^{\mathrm{T}}(\mathrm{P}-$ MZ5), with average biogas production of $406,2 \mathrm{ml}$ per $1 \mathrm{~g}$ $\mathrm{TVS}_{\text {substrate }}$. Mixtures with untreated microalgae (A) and different other pretreatments produced from 317 to 386 $\mathrm{ml}$ of biogas per $1 \mathrm{~g} \mathrm{TVS}$ substrate . The lowest production was measured in case of thermally pretreated microalgae (TA), with average production of $317,2 \mathrm{ml}$ of biogas per 1 $\mathrm{g} \mathrm{TVS}_{\text {substrate }}$ (Figure 2, C).

The lowest production of methane was measured in case of untreated microalgae (A), with average production of $176,9 \mathrm{ml}$ of methane per $1 \mathrm{~g} \mathrm{TVS}$ substrate. The highest methane production was recorded for mixtures with biologically pretreated microalgae (P-MZ5), with the average production of $279,9 \mathrm{ml}$ of methane per $1 \mathrm{~g} \mathrm{TVS}_{\text {substrate }}(\mathrm{Fi}-$ gure 2, D). The average percentage of methane in biogas in thermophilic process on the last day of BMP assay represented $61,1 \%$. The trend also showed that each of the

Table 2. BMP assay results showing cumulative methane production (at standard conditions) per $1 \mathrm{~g} \mathrm{TVS}_{\text {substrate }}(\mathrm{ml})$ in every experimental mixture for mesophilic and thermophilic anaerobic digestion of untreated, thermally, biologically and thermally-biologically treated microalgae. Legend: A - untreated microalgae, TA thermally pretreated microalgae, P-MZ5 - biologically pretreated microalgae (Mz5 culture added), P-MZ5a - negative control for biologically pretreated microalgae (autoclaved Mz5 culture added), P-MZ5-T - thermally and biologically pretreated microalgae (Mz5 culture added), P-MZ5a-T - negative control for thermally and biologically pretreated microalgae (autoclaved Mz5 culture added).

\begin{tabular}{|c|c|c|}
\hline \multirow[b]{2}{*}{ Bioreactor } & \multicolumn{2}{|c|}{$\begin{array}{c}\text { Cumulative methane production } \\
\text { per } 1 \mathrm{~g} \mathrm{TVS}_{\text {substrate }}(\mathrm{ml})\end{array}$} \\
\hline & Mesophilic process & Thermophilic process \\
\hline $\mathrm{A}$ & 217,2 & 176,9 \\
\hline TA & 273,2 & 187,1 \\
\hline P-MZ5 & 230,8 & 279,9 \\
\hline P-MZ5a & 238,6 & 242,4 \\
\hline P-MZ5-T & 254,1 & 231,7 \\
\hline P-MZ5a-T & 240,2 & 203,8 \\
\hline
\end{tabular}

Table 3. BMP assay results showing increase in biogas and methane production due to different methods of pretreatments in mesophilic and thermophilic anaerobic digestion. Effects of pretreatments were reckoned according to the comparison in pairs (e.g. thermally treated microalgae to untreated microalgae, etc.). Differences of cumulative production of biogas and methane per $1 \mathrm{~g} \mathrm{TVS}_{\text {substrate }}$ due to pretreatment effects between pairs were later expressed in percentages.

\begin{tabular}{lcccc}
\hline & \multicolumn{2}{c}{ Mesophilic process } & \multicolumn{2}{c}{ Thermophilic process } \\
& $\mathbf{C H}_{\mathbf{4}}$ & $\mathbf{B i o g a s}$ & $\mathbf{C H}_{\mathbf{4}}$ & Biogas \\
\hline Thermal pretreatment & $21 \%$ & $16 \%$ & $6 \%$ & $0 \%$ \\
Biological pretreatment & $0 \%$ & $0 \%$ & $13 \%$ & $5 \%$ \\
Thermal and biological pretreatment & $6 \%$ & $6 \%$ & $12 \%$ & $11 \%$ \\
\hline
\end{tabular}



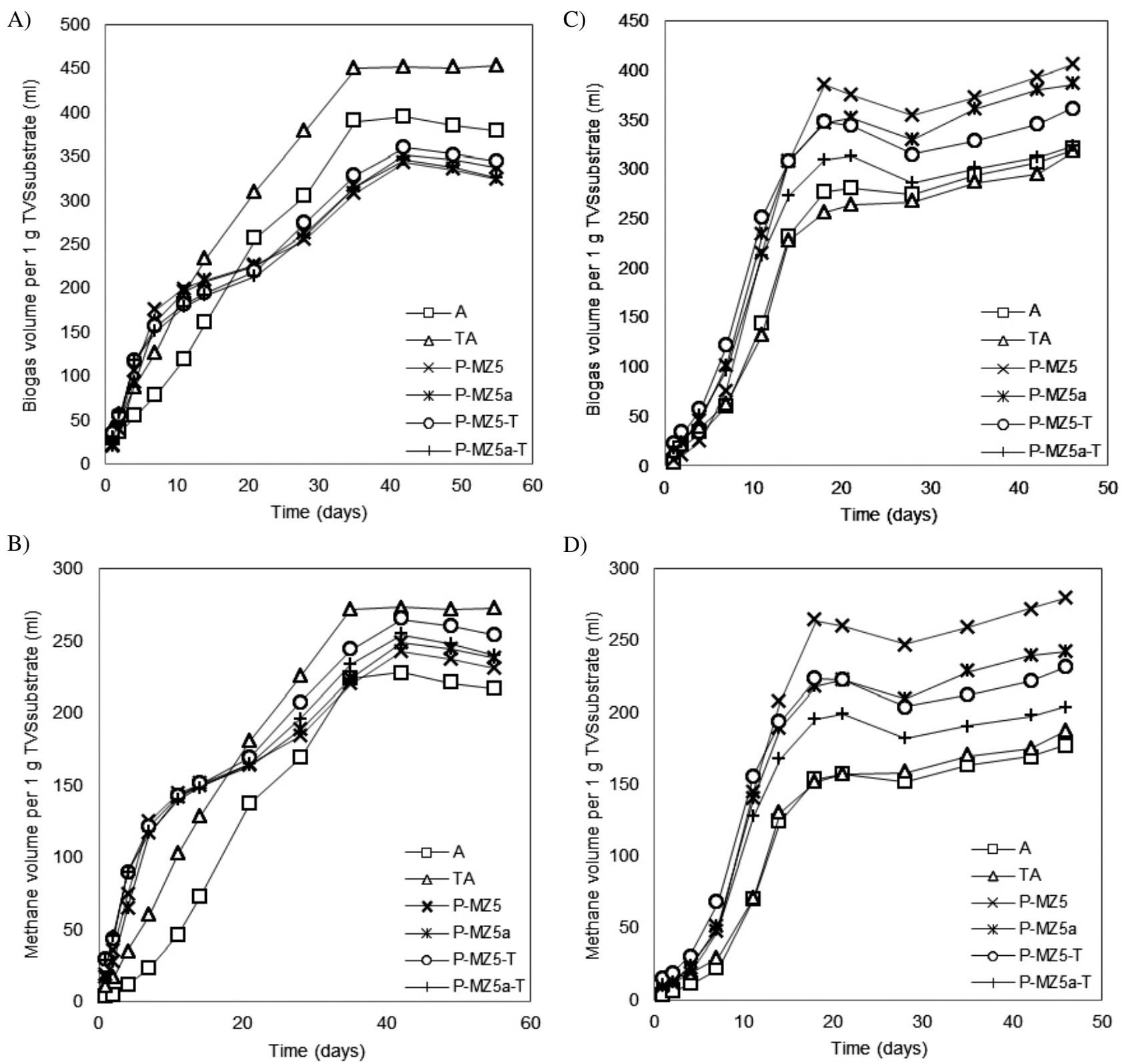

D)

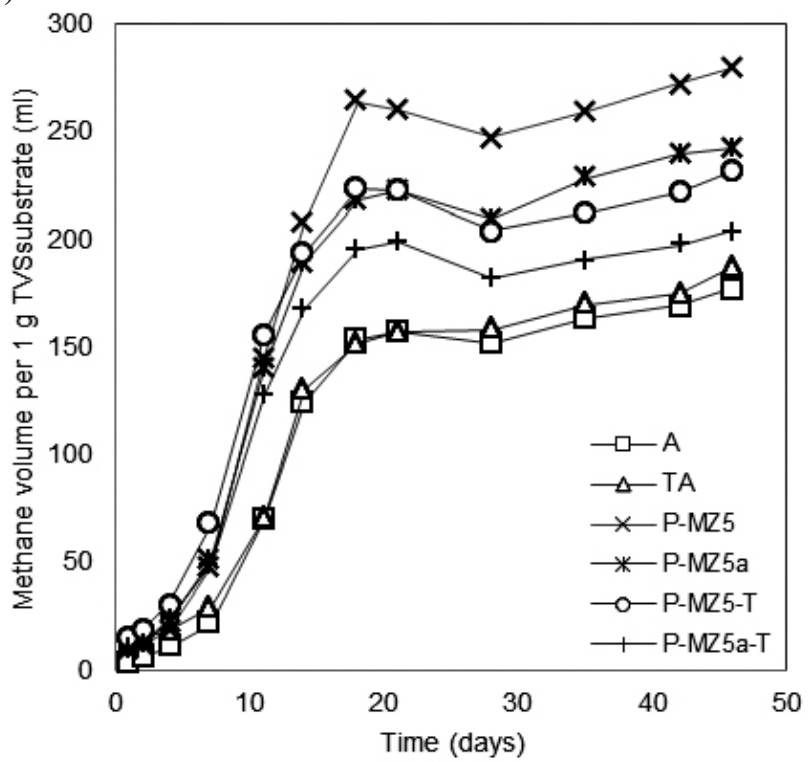

Figure 2. Cumulative biogas and methane production (at standard conditions) in mesophilic and thermophilic anaerobic digestion of untreated, thermally, biologically and thermally-biologically treated microalgae. A) biogas production per $1 \mathrm{~g} \mathrm{TVS}_{\text {substrate }}$ (ml) under mesophilic conditions, B) methane production per $1 \mathrm{~g} \mathrm{TVS}_{\text {substrate }}(\mathrm{ml})$ under mesophilic conditions, C) biogas production per $1 \mathrm{~g} \mathrm{TVS}$ substrate $($ ml) under thermophilic conditions, D) methane production per $1 \mathrm{~g} \mathrm{TVS}_{\text {substrate }}(\mathrm{ml})$ under thermophilic conditions. Legend: A - untreated microalgae, TA - thermally pretreated microalgae, P-MZ5 - biologically pretreated microalgae (Mz5 culture added), P-MZ5a - negative control for biologically pretreated microalgae (autoclaved Mz5 culture added), P-MZ5-T - thermally and biologically pretreated microalgae (Mz5 culture added), P-MZ5a-T - negative control for thermally and biologically pretreated microalgae (autoclaved Mz5 culture added).

pretreatments slightly increased the methane percentage in produced biogas (Table 3 ).

According to the literature, the thermophilic process shows $25-50 \%$ higher anaerobic activity compared to mesophilic. ${ }^{21}$ The temperature of anaerobic process affects the concentration and presence of individual SCFAs, which indicate that the accumulation of intermediates is in fact different under mesophilic and thermophilic conditions. Research results indicate that this feature depends mainly on the composition of microbial communities. ${ }^{22,23}$ For optimal process, the concentration of acetic acid should not be higher than $2 \mathrm{~g} \mathrm{l}^{-1}$ and concentration of propionic acid higher than $0,9 \mathrm{~g} \mathrm{l}^{-1}$. Increased concentration of propionic acid is the most significant indication of process inhibition ${ }^{45}$ and occurs following the acetic acid accumulation.

The highest total concentration of SCFAs in this study under mesophilic conditions was $1,4 \mathrm{~g}^{-1}$ (up to 1,3 
$\mathrm{g}^{-1}$ of acetic acid and up to $0,17 \mathrm{~g} \mathrm{l}^{-1}$ of propionic acid). In case of thermophilic BMP assay the highest total concentration of SCFAs was $1,3 \mathrm{~g} \mathrm{l}^{-1}$ (up to $1 \mathrm{~g} \mathrm{l}^{-1}$ of acetic acid and up to $0,22 \mathrm{~g} \mathrm{l}^{-1}$ of propionic acid). Acetic acid was the most abundant in all mixtures. SCFAs were within optimal concentration range during both experiments, with the lowest concentration at the end of BMP assays, demonstrating that anaerobic methanogenic degradation ran smoothly and with no inhibitory effects.

Optimum $\mathrm{pH}$ during anaerobic degradation varies between 6 and 8 , with optimum value around $\mathrm{pH}=7,5$ for thermophilic process ${ }^{46}$ and $\mathrm{pH}=7$ for mesophilic process. ${ }^{47}$ During our experiments the $\mathrm{pH}$ value ranged between 7,9 and 8,1 for mesophilic process and 7,8 and 8,2 for thermophilic process. Results were slightly higher than the optimal value, but still appropriate for stable biogas production.

Important parameter for determining the process activity is the reduction of the organic substance during anaerobic degradation. The content of TVS in thermophilic process has reduced by $22,3 \%$ and only by $9,0 \%$ in mesophilic process. The results indicate that the thermophilic anaerobic digestion is more efficient in decomposition of organic matter, which confirms the known facts about the thermophilic process. ${ }^{20}$

\section{2. Impact of Microalgae Pretreatments on Biogas and Methane Production}

\section{2. 1. Thermal Pretreatment}

Thermal pretreatment is recognized as possible and effective hydrolysis treatment for microalgae biomass. Higher temperature conditions stimulate cellulose and hemicellulose hydrolysis of algal cell wall components (mainly cellulose and hemicellulose), followed by formation and release of range of low molecular weight compounds (sugars, acids, etc.). ${ }^{38,48}$ Heat also disrupts the hydrogen bonds in crystalline cellulose, causing the biomass to swell.$^{38}$ It was found, that bonds between and within the molecules forming the microalgae Scenedesmus cell walls were cleaved during the thermal pretreatment at $90^{\circ} \mathrm{C}$, which resulted in increased methane production by 2,2-fold with regard to untreated microalgae. ${ }^{10}$ It is also known that time period of pretreatment is less important, as the temperature itself. ${ }^{49}$ The same conclusion had the research of Marsolek et al., where culture of Nannochloropsis oculata was treated at different temperatures. ${ }^{50}$ Temperatures between 30 and 60 ${ }^{\circ} \mathrm{C}$ did not increase decomposition, yet treatment at $90{ }^{\circ} \mathrm{C}$ caused partial decomposition, which allowed up to $36 \%$ increase in biogas production. High temperatures disintegrate algae cells already after 30 minutes of pretreatment, proving that thermal treatment improves the cellular contents release into extracellular space. ${ }^{10}$

The results of our study show that thermal pretreatment in mesophilic $\left(37^{\circ} \mathrm{C}\right) \mathrm{BMP}$ assay increased the bio- gas production by $16 \%$ and methane production by $21 \%$ in comparison to untreated microalgae (Table 3). Experimental results show that thermal pretreatment enables more efficient hydrolysis of microalgae cell wall compounds (especially cellulose and hemicellulose) and consequently releases more sugars for further efficient microbial transformation to biogas. The thermal pretreatment of microalgae also increased methane percentage in biogas and finally increased methane yield (Table 3 ). The results of BMP assay under thermophilic conditions $\left(55^{\circ} \mathrm{C}\right)$ did not show similar trends. Thermal pretreatment has not increased biogas production. Nevertheless, the methane production was increased, but only by $6 \%$ (Table 3 ). We can assume hypothetically, why thermal pretreatment has no significant effect on production in thermophilic process. One of the possible reasons may be the relatively low $\mathrm{C}: \mathrm{N}$ ratio, which can lead to the release and consequent increase in concentration of free ammonium during the thermal pretreatment of microalgae. ${ }^{35}$ Since thermophilic process is performed at higher temperatures than the mesophilic process, the anaerobic degradation of thermally pretreated microalgae can further disintegrate damaged algae cells. That can lead towards ammonium release, too, and thus to partial inhibition of methanogenic activity. ${ }^{19}$ Koster et al. have demonstrated the impact of free ammonia on anaerobic microorganisms and discovered that it rapidly penetrates through the cell membrane, causes proton imbalance, lack of potassium $\left(\mathrm{K}^{+}\right)$and enzyme inhibition. ${ }^{51}$ From the results we have obtained in our study, we can conclude that thermal pretreatment of microalgae at $90{ }^{\circ} \mathrm{C}$ (three hours) for thermophilic process is unnecessary, since the methane yield is not significantly higher than the methane yield from raw and untreated microalgae.

\section{2. 2. Biological Pretreatment}

Strains of genus Butyrivibrio represent a major proportion (10-30\%) of bacteria in the rumen of domestic and wild cattle. Many bacterial species of the genus Butyrivibrio contribute to the decomposition of fiber in the rumen. Most strains synthesize xylanase, amylase and cellodextrinase, some also 1,4- $\beta$-endoglucanses that can decompose a wide range of polymers. ${ }^{39} P$. xylanivorans $\mathrm{Mz}^{\mathrm{T}}$ is a close relative of bacterial species of the genus Butyrivibrio. It is a Gram-negative anaerobic bacterium that synthesizes many hydrolytic enzymes and holds excellent enzymatic activities. ${ }^{39,40}$

The results of BMP assay under mesophilic conditions showed that biological pretreatment of microalgae did not affect the production of biogas or methane (Table 3 ). It may be that during biological pretreatment a part of presented substrate is used for the growth of the microorganism used for the biological treatment itself, resulting in a loss of monomeric organic compounds left for the following methane production. More tests are needed 
to explain this phenomenon. The results of BMP assay under thermophilic conditions were somewhat different. Biological pretreatment increased biogas production by $5 \%$ and methane production by $13 \%$ (Table 3 ). The results show that bacterium $P$. xylanivorans $\mathrm{Mz}^{\mathrm{T}}$ managed to break down a certain proportion of hemicellulose, cellulose and xylan molecules in microalgae cell walls. This provided easier nutrient access for methanogenic microbial community during the thermophilic process, what consequently influenced the increase in methane production. $^{20-22}$

In the case of biological treatment it is more meaningful if we add live hydrolytic bacteria in to the process, which constantly produce extracellular enzymes and allow the hydrolysis of the substrate (bioaugmentation). ${ }^{50}$ The effect of biological pretreatment of microalgae on biogas production is still poorly understood, mainly due to the complexity of the structure of cell walls and species diversity of microalgae. Substrate that was applied for BMP assays contained mixed culture of microalgae in which certain types predominate, but are also changing seasonally. Therefore it is difficult to accelerate the hydrolysis of cell walls with only one bacterial strain. Microalgae are very diverse, thus we should choose an appropriate microorganism for each type or mixed culture and adjust the process of anaerobic degradation accordingly. ${ }^{50}$

\section{2. 3. Thermal-biological Pretreatment}

We also tested the influence of the combined pretreatment (thermal-biological) of microalgae on biogas production by BMP assays. The above-mentioned pretreatment showed no significant effect on biogas or methane production in mesophilic process (Table 3 ). Production of biogas and methane was increased by $6 \%$. Results were similar when the microalgae were only biologically pretreated. Comparing all tested pretreatments (thermal, biological, thermal-biological) of microalgae to produce biogas and methane, we found that only thermal pretreatment maximizes production in mesophilic process. The results of BMP assay under thermophilic conditions showed that thermal-biological pretreatment increases the biogas production by $11 \%$ and methane production by $12 \%$ (Table 3). According to the results, combined pretreatment of microalgae indicates stronger effect on thermophilic process than individual pretreatments. This result could be explained by the fact that during biological pretreatment a part of substrate presented after thermal pretreatment was used for the growth of the bacteria used for the biological treatment itself, resulting in loss of substrate in the system left for the following methane production. Although it is generally accepted that thermophilic anaerobic digestion is more efficient than mesophilic anaerobic digestion of the same substrate, our results have not proved that for microalgae. It has been calculated from data in Table 2 that the average cumulative biogas production in mesophilic process is more efficient for $2 \%$ and the average cumulative methane production for $9 \%$ (Table 2) than in thermophilic process. There were also differences in the methane yield, where the average yield of methane in mesophilic process was higher for $9 \%$ in comparison to thermophilic process (Table 3 ).

\section{Conclusions}

In order to accelerate anaerobic digestion we applied different types of pretreatments of microalgae. Following the obtained results, we can conclude that thermal pretreatment at $90{ }^{\circ} \mathrm{C}$ is the most effective method for increasing methane and biogas production under mesophilic conditions. Biogas production was increased by $16 \%$ and methane production by $21 \%$. Biological pretreatment with bacterium $P$. xylanivorans $\mathrm{Mz}^{\mathrm{T}}$ is the most effective method for increasing methane and biogas production under thermophilic conditions. Methane production was increased by $13 \%$. Combined (thermal-biological) pretreatment showed the strongest effect in thermophilic process. Biogas production was increased by $11 \%$ and methane production by $12 \%$. Further research should be carried out to determine which pretreatments are the most economical for individual biogas plant and which algae species are the best for biofuel production, before we could transfer the research to higher scale.

\section{Acknowledgements}

The authors would like to thank to the two Slovenian biogas plants Koto d.o.o. and Petrol d.d. for their cooperation during this research.

\section{References}

1. A. Cadenas, S. Cabezudo, Technol. Forecast. Soc. Change. 1998, 58, 83-103.

http://dx.doi.org/10.1016/S0040-1625(97)00083-8

2. R. E. H. Sims, W. Mabee, J. N. Saddler, Bioresour. Technol. 2010, 101, 1570-1580.

http://dx.doi.org/10.1016/j.biortech.2009.11.046

3. G. Dragone, B. Fernandes, A. Vicente, J. Teixeira, Curr. Res. Technol. Educ. Top. Appl. Microbiol. Microb. Biotechnol. 2010, Formatex, 1355-1366.

4. D. Russo, M. Dassisti, V. Lawlor, A. G. Olabi, Renew. Sustain. Energy Rev. 2012, 16, 4056-4070.

http://dx.doi.org/10.1016/j.rser.2012.02.024

5. P. M. Schenk, S. R. Thomas-Hall, E. Stephens, U. C. Marx, J. H. Mussgnug, C. Posten, O. Kruse, B. Hankamer, BioEnergy Res. 2008, 1, 20-43.

http://dx.doi.org/10.1007/s12155-008-9008-8 
6. A. Demirbas, Energy Conversion and Management. 2009, 50, 2239-2249. http://dx.doi.org/10.1016/j.enconman.2009.05.010

7. Y. Li, M. Horsman, N. Wu, C. Q. Lan, N. Dubois-Calero, Biotechnol. Prog. 2008, 24, 815-820. http://dx.doi.org/10.1021/bp.070371k

8. P. E. Wiley, J. E. Campbell, B. McKuin, Water Environ. Res. 2011, 83, 326-338.

9. L. Lardon, A. Hélias, B. Sialve, J. - P. Steyer, O. Bernard, Environ. Sci. Technol. 2009, 43, 6475-6481. http://dx.doi.org/10.1021/es900705j

10. C. González-Fernández, B. Sialve, N. Bernet, J. - P. Steyer, Biomass and Bioenergy. 2012, 40, 105-111. http://dx.doi.org/10.1016/j.biombioe.2012.02.008

11. I. Angelidaki, W. Sanders, Rev. Environ. Sci. Biotechnol. 2004, 3, 117-129. http://dx.doi.org/10.1007/s11157-004-2502-3

12. H. M. El-Mashad, G. Zeeman, W. K. P. Van Loon, G. P. A. Bot, G. Lettinga, Bioresour. Technol. 2004, 95, 191-201. http://dx.doi.org/10.1016/j.biortech.2003.07.013

13. J. S. Zhang, K. W. Sun, M. C. Wu, L. Zhang, J Environ Sci (China). 2006, 18, 810-815.

14. M. D. Ghatak, P. Mahanta, Int. J. Adv. Res. Technol. 2014, 1, $1-7$.

15. C. Vanegas, J. Bartlett, Waste and Biomass Valorization, 2013, 4, 509-515. http://dx.doi.org/10.1007/s12649-012-9181-z

16. D. R. Kashyap, K. S. Dadhich, S. K. Sharma, Bioresour. Technol. 2003, 87, 147-153. http://dx.doi.org/10.1016/S0960-8524(02)00205-5

17. V. Kinnunen, R. Craggs, J. Rintala, Water Res. 2014, 57, 247-257. http://dx.doi.org/10.1016/j.watres.2014.03.043

18. H. K. Ravuri, Int. J. Adv. Chem. 2013, 1, 31-38. http://dx.doi.org/10.14419/ijac.v1i2.1318

19. J. L. Chen, R. Ortiz, T. W. J. Steele, D. C. Stuckey, Biotechnol. Adv. 2014, 32, 1523-1534. http://dx.doi.org/10.1016/j.biotechadv.2014.10.005

20. P. Vindis, B. Mursec, M. Janzekovic, F. Cus, J. Achiev. Mat. Man. Eng. 2009, 36, 192-198.

21. M. H. Gerardi: The Microbiology of Anaerobic Digesters, John Wiley \& Sons, Inc., Hoboken, New Jersey, 2003, pp. 77-121. http://dx.doi.org/10.1002/0471468967.ch17

22. P. Chaiprasert, S. Bhumiratana, M. Tanticharoen, Thammasat Int. J. Sc. Tech. 2001, 6, 1-9.

23. M. Čater, L. Fanedl, R. Marinšek Logar, Acta Chim. Slov. 2013, 60, 243-255.

24. D. Novak, B. Stres, G. Osojnik, I. Škrjanec, R. Marinšek Logar, Acta Chim. Slov. 2011, 58, 171-175.

25. H. Bouallagui, Y. Touhami, R. Ben Cheikh, M. Hamdi, Process Biochem. 2005, 40, 989-995. http://dx.doi.org/10.1016/j.procbio.2004.03.007

26. E. Marinho-Soriano, P. C. Fonseca, M. A. A. Carneiro, W. S. C. Moreira, Bioresour. Technol. 2006, 97, 2402-2406. http://dx.doi.org/10.1016/j.biortech.2005.10.014

27. T. Bruton, H. Lyons, Y. Lerat, M. Stanley, M. B. Rasmussen, A Review of the Potential of Marine Algae as a Source of
Biofuel in Ireland, http://www.seai.ie/Publications/Renewables_Publications_/Bioenergy/Algaereport.pdf, (assessed: April 22, 2016)

28. S. M. Renaud, L. - V. Thinh, D. L. Parry, Aquaculture. 1999, 170, 147-159.

http://dx.doi.org/10.1016/S0044-8486(98)00399-8

29. E. W. Becker, Biotechnol Adv. 2007, 25, 207-210. http://dx.doi.org/10.1016/j.biotechadv.2006.11.002

30. E. Percival, Br. Phycol. J. 1979, 14, 103-117. http://dx.doi.org/10.1080/00071617900650121

31. L. Yao, J. A. Gerde, S. - L. Lee, T. Wang, K. A. Harrata, J. Agric. Food Chem. 2015, 63, 1773-1787. http://dx.doi.org/10.1021/jf5050603

32. A. J. Ward, D. M. Lewis, F. B. Green, Algal Res. 2014, 5, 204-214. http://dx.doi.org/10.1016/j.algal.2014.02.001

33. C. Ververis, K. Georghiou, D. Danielidis, D. G. Hatzinikolaou, P. Santas, R. Santas, V. Corleti, Bioresour. Technol. 2007, 98, 296-301. http://dx.doi.org/10.1016/j.biortech.2006.01.007

34. X. Briand, P. Morand, J. Appl. Phycol. 1997, 9, 511-524. http://dx.doi.org/10.1023/A:1007972026328

35. M. E. Montingelli, S. Tedesco, A. G. Olabi, Renew. Sustain. Energy Rev. 2015, 43, 961-972.

http://dx.doi.org/10.1016/j.rser.2014.11.052

36. I. Sorensen, D. Domozych, W. G. T. Willats, Plant Physiol. 2010, 153, 366-372. http://dx.doi.org/10.1104/pp.110.154427

37. C. - Z. Liu, F. Wang, A. R. Stiles, C. Guo, Appl. Energy. 2012, 92, 406-414.

http://dx.doi.org/10.1016/j.apenergy.2011.11.031

38. C. Rodriguez, A. Alaswad, J. Mooney, T. Prescott, A. G. Olabi, Fuel Process. Technol. 2015, 138, 765-779. http://dx.doi.org/10.1016/j.fuproc.2015.06.027

39. J. Kopečný, M. Zorec, J. Mrázek, Y. Kobayashi, R. Marinšek Logar, Int. J. Syst. Evol. Microbiol. 2003, 53, 201-209. http://dx.doi.org/10.1099/ijs.0.02345-0

40. T. Čepeljnik, I. Križaj, R. Marinšek Logar, Enzyme Microb. Technol. 2004, 34, 219-227. http://dx.doi.org/10.1016/j.enzmictec.2003.10.012

41. APHA/AWWA/WEF, Standard Methods for the Examination of Water and Wasterwater, https://www.standardmethods.org/, (assessed: 2006)

42. M. Čater, L. Fanedl, Š. Malovrh, R. Marinšek Logar, Bioresour. Technol. 2015, 186, 261-269.

http://dx.doi.org/10.1016/j.biortech.2015.03.029

43. T. L. Hansen, J. E. Schmidt, I. Angelidaki, E. Marca, J. C. Jansen, H. Mosbak, T. H. Christensen, Waste Manag. 2004, 24, 393-400.

http://dx.doi.org/10.1016/j.wasman.2003.09.009

44. M. A. T. Adorno, J. S. Hirasawa, M. B. A. Varesche, Am. J. Anal. Chem. 2014, 5, 406-414.

http://dx.doi.org/10.4236/ajac.2014.57049

45. I. H. Franke-Whittle, A. Walter, C. Ebner, H. Insam, Waste Manag. 2014, 34, 2080-2089.

http://dx.doi.org/10.1016/j.wasman.2014.07.020

46. L. Yang, Y. Huang, M. Zhao, Z. Huang, H. Miao, Z. Xu, W. 
Ruan, Int. Biodeterior. Biodegrad. 2015, 105, 153-159. http://dx.doi.org/10.1016/j.ibiod.2015.09.005

47. A. E. Cioabla, I. Ionel, G. - A. Dumitrel, F. Popescu, Biotechnol. Biofuels. 2012, 5, 39-48.

http://dx.doi.org/10.1186/1754-6834-5-39

48. M. Sežun, V. Grilc, G. D. Zupančič, R. Marinšek Logar, Acta Chim. Slov. 2011, 58, 158-166.

49. R. T. Haug, D. C. Stuckey, J. M. Gossett, P. L. McCarty, Wa- ter Pollut. Control Fed. 1978, 50, 73-85.

50. M. D. Marsolek, E. Kendall, P. L. Thompson, T. R. Shuman, Bioresour. Technol. 2014, 151, 373-377. http://dx.doi.org/10.1016/j.biortech.2013.09.121

51. I. W. Koster, G. Lettinga, Agric. Wastes. 1984, 9, 205-216. http://dx.doi.org/10.1016/0141-4607(84)90080-5

52. F. Lü, J. Ji, L. Shao, P. He, Biotechnol. Biofuels. 2013, 6, 92-103. http://dx.doi.org/10.1186/1754-6834-6-92

\section{Povzetek}

Pri iskanju novih alternativnih virov energije ima velik potencial odpadna biomasa. V zadnjem času se pozornost preusmerja tudi na neobičajne vire, na primer mikroalge, ki jih lahko uporabimo kot substrat za proizvodnjo bioplina v anaerobni razgradnji. Mikroalge imajo težko razgradljive celične stene, kar ovira učinkovitost anaerobnega procesa. Za pospešitev hidrolize in povečanje proizvodnje bioplina iz mikroalg smo uporabili dva načina predobdelave - biološko in termično v mezofilnih in termofilnih pogojih. Pri biološkem načinu smo mikroalge pred poskusom inkubirali s hidrolitskimi bakterijami Pseudobutyrivibrio xylanivorans $\mathrm{Mz}^{\mathrm{T}}$. Pri termični predobdelavi smo mikroalge inkubirali pri 90 ${ }^{\circ} \mathrm{C}$. Preizkusili smo tudi kombinirano termično-biološko predobdelavo, kjer smo mikroalge po termični obdelavi inkubirali s P. xylanivorans $\mathrm{Mz}^{\mathrm{T}}$. Termična predobdelava je v mezofilnem procesu povečala proizvodnjo metana za $21 \%$, $\mathrm{v}$ termofilnem procesu le za $6 \%$. Biološka predobdelava mikroalg je povečala proizvodnjo metana samo v termofilnih pogojih in sicer za $13 \%$ (predobdelava v mezofilnem procesu ni imela večjega vpliva). Termično-biološka predobdelava je v termofilnih pogojih povečala proizvodnjo metana za $12 \%$, v mezofilnih pogojih pa za $6 \%$. 